\title{
FEATURES OF DOCTORS LIFE-WORLD STABILITY DURING THE PANDEMIC COVID-19
}

\author{
Olga V. Petryaeva ${ }^{1}, \&$ Irina O. Loginova ${ }^{2}$ \\ ${ }^{1}$ Federal State-Financed Institution Federal Siberian Research Clinical Centre under the Federal \\ Medical Biological Agency (Russia) \\ ${ }^{2}$ Professor V.F. Voyno-Yasenetsky Krasnoyarsk State Medical University (Russia)
}

\begin{abstract}
Statement of the problem. The article formulates the problem and purpose of a study focused on identifying the characteristics of the doctors life-world stability during the pandemic associated with COVID-19. The problem of this study is due to the contradiction between the desire of people for stability, certainty, the ability to control their lives and the circumstances and conditions of the pandemic regime that limit people in such aspirations and opportunities.

Purpose of the article: to recognize the characteristics of the doctors life-world stability during the pandemic associated with COVID-19.

Methodology (materials and methods). The research methodology was composed of systemic anthropological psychology, which allows a person's living space to be considered as his (human) not linear, but multivariate future. At the same time, it becomes possible to consider the processes of self-fulfillment in space and time (chronotope), that is, in a life scan that has not yet taken place, but which a person is a part of. The methodological potential of systemic anthropological psychology in conjunction with the conceptual foundations of the theory of life self-fulfillment allows us to consider the human life-world stability as an opportunity for life self-realization of the project of one's life. This project just makes up such a characteristic of a person that can manifest itself precisely in the processes of life's self-fulfillment. In order to maintain the chronotopic logic of human life in the context of this study, we used the author's methodology "Study of the human life-world stability" (Loginova, 2012). The total sample size was 78 doctors: 58 - doctor on duty; 20 - attending doctor.

Research results. For the first time, data were obtained on the characteristics of the doctors life-world stability during the pandemic associated with COVID-19. The specifics of changing the time mode of events, the emotional background, the continuity of personal history and the decrease in reflexivity are key. According to the above parameters, significant differences were found in the indicators before the events associated with the special epidemiological regime of the pandemic caused by COVID-19 and during the pandemic.

Conclusions in accordance with the purpose of the article. The materials presented will allow psychologists to take these results into account when working with doctors who have particularly experienced the period of the pandemic associated with COVID-19, keeping these parameters in focus as targets for psychological assistance. The obtained data actualizes the need to develop special psychological support programs when leaving the special epidemiological regime of a pandemic.
\end{abstract}

Keywords: Systemic anthropological psychology, human life-world stability, living space, opportunities for life self-fulfillment, pandemic, COVID-19.

\section{Introduction}

The problem of this study is due to the contradiction between the desire of people for stability, certainty, the ability to control their lives and the circumstances and conditions of the pandemic regime that limit people in such aspirations and opportunities.

The problem of all mankind, faced with the CoVid-19 pandemic, is that every person, regardless of gender, education, social status and other characteristics, finds himself in a situation of broken relations with a previously familiar and understandable world, which can be summarized as adverse mental health effects [Rajkumar, 2020, c. e102066].People who are used to planning their lives months ahead, choosing ways of interacting with the social environment, at one point found themselves in a situation of frustrated opportunities. Thus, the pandemic brings a lot of uncertainty, which makes it difficult to meet even basic 
human needs [Fiedorowicz, 2020, c. e110123]. While large numbers of people around the world will demonstrate resilience to the profound loss, stress and fear associated with COVID-19, the virus is likely to exacerbate existing mental health conditions and contribute to the emergence of new stress-related disorders for many [Horesh et al., 2020, c. 331]. In critical (even extreme) changing conditions of life, the role of issues of psychological assistance undoubtedly increases, which plays a decisive role in restoring and maintaining emotional stability [Wang et al., 2020, p. 733], which means, to a certain extent, the stability of the human life world.

\section{Purpose of the article}

To recognize the characteristics of the doctors life-world stability during the pandemic associated with COVID-19.

\section{Methodology (materials and methods)}

The research methodology was composed of systemic anthropological psychology, which allows a person's living space to be considered as his (human) not linear, but multivariate future. At the same time, it becomes possible to consider the processes of self-fulfillment in space and time (chronotope), that is, in a life scan that has not yet taken place, but which a person is a part of. The methodological potential of systemic anthropological psychology in conjunction with the conceptual foundations of the theory of life self-fulfillment allows us to consider the human life-world stability as an opportunity for life self-realization of the project of one's life. This project just makes up such a characteristic of a person that can manifest itself precisely in the processes of life's self-fulfillment. In order to maintain the chronotopic logic of human life in the context of this study, we used the author's methodology "Study of the human life-world stability" (Loginova, 2012). The total sample size was 78 doctors: 58 - doctor on duty (first group); 20 - attending doctor (second group).

At the preliminary stage, those who did not fill out the proposed questionnaires in full, as well as those who did not meet the following criteria, were excluded from the sample:

- voluntary consent to participate in the research;

- men and women between the ages of 25 and 55.

Statistical analysis of empirical data was carried out using the statistical package IBM SPSS Statistics v.19. Verification of quantitative data for obedience to the law of normal distribution was carried out using the Shapiro-Wilk test. Quantitative data are presented in the form of arithmetic means, qualitative data - in percent. Comparison of qualitative characteristics between the study groups was carried out using Fisher's exact test, quantitative characteristics - the Mann-Whitney test due to the absence of a normal distribution of variables.

The critical value of the significance level was taken as $\mathrm{p}<0.05$

The collection of empirical data was carried out from March 30 to May 28, 2020. Processing, analysis and interpretation - from May 29 to June 07, 2020.

\section{Results}

The first stage of the study was devoted to checking the groups for comparability. We found that the groups of doctors on duty and attending doctors are identical in composition. This fact allowed us to conduct a comparative analysis of the doctors life-world stability.

For the first time, data were obtained on the characteristics of the doctors life-world stability during the pandemic associated with COVID-19.

This comparative analysis shows that in a pandemic the retention of the past line is more pronounced (this is evidenced by the events described by the respondents and the verbs they use in the story). The share of the past in a pandemic significantly exceeds the representation of the present. A number of authors point out similar effects manifested in time management problems [Mackolil et al., 2020, p. e102156], which confirms our research position. The support in the growing negative emotional background $(50 \%)$ is a responsible attitude $(50 \%)$ to events in life. A decrease or complete rejection of the value attitude towards life events in favor of a responsible person leads to a violation of personal history, to a significant deficiency of the reflexive position.

The specifics of changing the time mode of events, the emotional background, the continuity of personal history and the decrease in reflexivity are key. 
Table 1. Results of the doctors life-world stability of two groups.

\begin{tabular}{|c|c|c|}
\hline Options & First group & Second group \\
\hline $\begin{array}{l}\text { Temporary of events } \\
\text { tendency }\end{array}$ & $\begin{array}{l}\text { The present - the future } 60 \% \\
\text { The past - the present - the future } 40 \%\end{array}$ & $\begin{array}{l}\text { The present }-20 \% \\
\text { The past }-40 \% \\
\text { The past and the present }-40 \%\end{array}$ \\
\hline The ratio of verbs & $\begin{array}{l}\text { The present - the future } 60 \% \\
\text { The past - the present - the future } 40 \%\end{array}$ & $\begin{array}{l}\text { The present }-20 \% \\
\text { The past }-40 \% \\
\text { The past and the present }-40 \%\end{array}$ \\
\hline $\begin{array}{l}\text { Criterion for the described } \\
\text { events content selecting }\end{array}$ & $\begin{array}{l}\text { Chronotopic } 30 \% \\
\text { Topological } 60 \% \\
\text { Biographical } 10 \% \\
\end{array}$ & $\begin{array}{l}\text { Chronotopic } 20 \% \\
\text { Topological } 30 \% \\
\text { Biographical } 50 \% \\
\end{array}$ \\
\hline $\begin{array}{l}\text { General emotional } \\
\text { background of events }\end{array}$ & $\begin{array}{l}\text { Positive } 60 \% \\
\text { Neutral } 30 \% \\
\text { Negative } 10 \%\end{array}$ & $\begin{array}{l}\text { Positive } 20 \% \\
\text { Neutral } 30 \% \\
\text { Negative } 50 \%\end{array}$ \\
\hline $\begin{array}{l}\text { The meaning of the } \\
\text { described life events }\end{array}$ & $\begin{array}{l}\text { The overall direction of the development } \\
\text { line is conserved } 50 \% \\
\text { General orientation is not withheld } 30 \% \\
\text { The beginning of the development line } \\
20 \%\end{array}$ & $\begin{array}{l}\text { The overall direction of the } \\
\text { development line is conserved } 10 \% \\
\text { General orientation is not withheld } \\
20 \% \\
\text { The beginning of the development } \\
\text { line } 70 \%\end{array}$ \\
\hline Attitude to events & $\begin{array}{l}\text { Value } 60 \% \\
\text { Responsible } 20 \% \\
\text { Rational } 20 \% \\
\end{array}$ & $\begin{array}{l}\text { Value } 20 \% \\
\text { Responsible } 60 \% \\
\text { Rational } 20 \% \\
\end{array}$ \\
\hline $\begin{array}{l}\text { Continuity of personal } \\
\text { history }\end{array}$ & $\begin{array}{l}\text { Retained } 75 \% \\
\text { Situationally } 20 \% \\
\text { Missing } 5 \%\end{array}$ & $\begin{array}{l}\text { Retained } 0 \% \\
\text { Situationally } 30 \% \\
\text { Missing } 70 \%\end{array}$ \\
\hline Author reflexive position & $\begin{array}{l}\text { Holistic reflexive position } 60 \% \\
\text { Situational reflexive attitude } 25 \% \\
\text { Absence of a reflexive relation } 10 \%\end{array}$ & $\begin{array}{l}\text { Holistic reflexive position } 10 \% \\
\text { Situational reflexive attitude } 30 \% \\
\text { Absence of a reflexive relation } 60 \%\end{array}$ \\
\hline
\end{tabular}

According to the above parameters, significant differences in indicators were revealed in two groups of doctors. To assess the significance of differences in the parameters of the stability of the life world in the groups of respondents, the Student's t-test was applied for unrelated samples with a mandatory check of distribution norms and calculation of standard deviation.

The results presented in Table 2 allow us to state that there is a significant difference between the stability of the life world of the attending physicians and the doctors on duty. It can be assumed that changes in the lifestyle of doctors on duty in the context of a pandemic cannot yet be fully considered critical, but they indicate the alleged targets of psychological assistance at the end of this period.

Table 2. Assessment of differences in the characteristics of the doctors life-world stability of respondents by the t-test for related samples.

\begin{tabular}{|c|c|c|c|c|c|}
\hline \multicolumn{2}{|c|}{ First group } & \multicolumn{2}{c|}{ Second group } & \multirow{2}{*}{ t-test } & \multirow{2}{*}{$\mathrm{p}$} \\
\cline { 1 - 3 } & $\delta$ & $\mu$ & $\delta$ & & \\
\hline 31,73 & 8,31 & 27,92 & 7,46 & 1,997 & 0,05 \\
\hline
\end{tabular}

According to a number of authors who have previously described the psychological consequences of the pandemic of the respiratory syndrome epidemic in the Middle East, existing problems begin to be minimized four to six months after release from isolation, along with the provision of psychological support for people with vulnerable mental health, as well as the provision of accurate information [Jeong et al., 2016, p. e2016048].

\section{Conclusions}

The characteristics of the stability of the life world of doctors on duty, in contrast to attending doctors in a pandemic associated with COVID-19, are

- domination of the temporal mode "past - present";

- disrupted continuity of personal history;

- biography as a criterion for choosing the content of the described (significant) events;

- dominant negative emotional background of events;

- absent or situational reflexive attitude towards one's own life; 
- significant events more often characterize the central line of development or the completion of the line of development, and in some cases, significant and important events do not hold the general line of development.

Thus, it can be stated that disturbed relations with the world in a pandemic, which impede the maintenance of the stability of the life world, are more pronounced among the doctors on duty. The specificity of the stability of the life world of people according to the above parameters is close to the state of stability of the life world in a crisis period for a person.

The materials presented will allow psychologists to take these results into account when working with doctors who have particularly experienced the period of the pandemic associated with COVID-19, keeping these parameters in focus as targets for psychological assistance. The obtained data actualizes the need to develop special psychological support programs when leaving the special epidemiological regime of a pandemic.

\section{References}

Cai W., Lian B., Song X., (...), Deng G., Li H. A cross-sectional study on mental health among health care workers during the outbreak of Corona Virus Disease 2019 // Asian Journal of Psychiatry, 2020, Vol. 51, e102111. DOI: 10.1016/j.ajp.2020.102111

Fiedorowicz Jess G. New challenges in the COVID-19 pandemic // Journal of Psychosomatic Research, 2020, Vol. 133, e110123. DOI: https://doi.org/10.1016/j.jpsychores.2020.110123

Horesh, D., Brown, A.D. Covid-19 response: Traumatic stress in the age of Covid-19: A call to close critical gaps and adapt to new realities // Psychological Trauma: Theory, Research, Practice, and Policy, 2020, Vol. 12(4), P. 331-335. DOI: 10.1037/tra0000592

Jeong H., Yim H.W., Song Y.-J., (...), Cho J., Chae J.-H. Mental health status of people isolated due to Middle East Respiratory Syndrome // Epidemiology and health, 2016, Vol. 38, P. e2016048. DOI: https://doi.org/10.4178/epih.e2016048

Lai J., Ma S., Wang Y., Cai Z., Hu J., Wei N., ... Hu S. Factors associated with mental health outcomes among health care workers exposed to coronavirus disease 2019 // JAMA Netw Open, 2020, Vol. 3(3): e203976. URL: https://jamanetwork.com/journals/jamanetworkopen/fullarticle/2763229

Lee A. M., Wong J. G., McAlonan G. M., Cheung V., Cheung C., Sham P. C., ... Chua S. E. Stress and psychological distress among SARS survivors 1 year after the outbreak // Canadian Journal of Psychiatry. Revue Canadienne de Psychiatrie, 2007, Vol. 52(4), P. 233-240. DOI: $10.1177 / 070674370705200405$

Loginova I.O. [The study of the human life-world stability: methodology and psychometric characteristics] // Psihologicheskaja nauka i obrazovanie [Psychological Science and Education]. - 2012. - № 3. - S. 18-28. URL: https://psyjournals.ru/psyedu/2012/n3/54338.shtml (In Russ.).

Mackolil J., Mackolil J. Addressing psychosocial problems associated with the COVID-19 lockdown // Asian Journal of Psychiatry, 2020, Vol. 51, e102156. DOI: https://doi.org/10.1016/j.ajp.2020.102156

Marques L., Bartuska F.D., Cohen J.N., Youn S.J. Three steps to flatten the mental health need curve amid the COVID-19 pandemic // Depression and Anxiety, 2020, Vol.1-2, e23031. DOI: https://doi.org/10.1002/da.23031

Rajkumar R.P. COVID-19 and mental health: A review of the existing literature // Asian Journal of Psychiatry, 2020, Vol. 52, e102066. DOI: https://doi.org/10.1016/j.ajp.2020.102066

Wang Y., Zhao X., Feng Q., (...), Yao Y., Shi J. Psychological assistance during the coronavirus disease 2019 outbreak in China // Journal of Health Psychology, 2020, Vol. 25(6), P. 733-737. DOI: $10.1177 / 1359105320919177$ 